DOI https://doi.org/10.30525/978-9934-26-173-2-7

\title{
МЕХАНІЗМ ВЗАСМОДІЇ УЧАСНИКІВ ОСВІТНЬОГО ПРОЦЕСУ ПРИ СТВОРЕННІ БЕЗПЕЧНОГО ПСИХОЛОГІЧНОГО СЕРЕДОВИЩА
}

\author{
Щирова Т. О. \\ практичний психолог \\ Новотроӥцька загальноосвітня школа I-III ступенів № 4 \\ смт Новотроӥцьке, Ольгинська ОТГ, Волноваський район, \\ Донецька область, Украӥна
}

В сучасному суспільстві заклади загальної середньої освіти переходять на новий рівень надання навчальних послуг. Поруч із забезпеченням якості освіти одним із пріоритетних принципів сучасної школи залишається створення безпечного освітнього середовища. Так, на думку А. Маслоу, «Потреба в безпеці у дітей проявляється в їхньому потягу до сталості, до впорядкування повсякденного життя. Дитині явно більше до смаку, коли навколишній світ передбачуваний, розмірений, організований» [1, с. 65].

В різні часи учасники освітнього середовища опинялись в певних небезпечних ситуаціях, пов'язаних з ризиком для фізичного здоров'я, психологічного благополуччя. Система безпеки освітніх закладів модернізується, забезпечується сучасними засобами безпеки, регламентується великою кількістю нормативно-правових документів, актів, Законів. В закладах освіти регулярно проводяться тренувальні заняття з евакуації під час пожеж, заняття з безпеки дорожнього руху, обладнані інформаційні стенди, в різноманітних Інтернет-джерелах розміщені інформаційні матеріали, практичними психологами здійснюється просвітницька, профілактична, корекційна робота. Здається, в закладах освіти враховані всі чинники ризику для фізичного, психологічного здоров'я, але ж кількість фізичних ушкоджень, психологічних травм невпинно зростає. В чому полягає причина?

Події останніх років свідчать про те, що постраждати можуть як окремі учні, так і цілі групи, навіть громади.

Зріс відсоток дітей з психічним розладами, порушеннями емоційновольової сфери, підвищився рівень тривожності, агресії, невпевненості. Психологічна безпека особистості невід'ємно пов'язана з фізичним здоров'ям.

I.O. Баєва дає наступне визначення психологічної безпеки освітнього середовища закладів освіти - «це середовище, вільне від проявів 
психологічного насильства у взаємодії, яке сприяє задоволенню потреб у особистісно-довірчому спілкуванні, створює референтну значимість середовища та забезпечує психічне здоров'я учасників навчальновиховного процесу» [2, с. 34]

У кризових ситуаціях психічні та інші перенавантаження досягають межі, за якими наступають нервове виснаження, перевтома, афективні реакції. Кризові життєві ситуації несуть в собі небезпеку для життя, здоров'я, благополуччя особистості. Психологічна безпека в освітньому закладі сприяє гармонійному розвитку здобувачів освіти, розкриттю талантів, обдаровань.

Аналіз ситуації свідчить про те, що переважну більшість небезпек несуть в собі люди, і лише певну частку події та обставини які не залежать від учасників освітнього процесу. Таким чином, допомогти вирішити та подолати певні чинники ризику можуть самі здобувачі освіти. Доцільним $є$ створення комітету безпеки школи, який очолюють самі учні. На меті комітету виступає попередження, захист учасників освітнього середовища від проявів насильства, булінгу, можливих небезпек та загроз життю та здоров'ю.

Для реалізації мети комітету безпеки необхідно вирішувати низку завдань:

- виявлення та попередження небезпечних ситуацій в освітньому закладі;

- побудова довірливих стосунків 3 всіма учасниками освітнього процесу;

- ознайомлення з практичними прийомами створення толерантного та безпечного середовища в освітньому закладі;

- створення фізично, психологічно комфортної атмосфери, сприятливої для всебічного розвитку особистості;

- відпрацювання системи дій членів комітету безпеки в різних ситуаціях.

В своїй роботі комітет безпеки керується наступними принципами:

- науковості - діяльність членів комітету грунтується на основі сучасних наукових досягнень в області педагогіки та психології;

- гуманізації - надається пріоритет інтересам, можливостям дітей;

- принцип індивідуального підходу - врахування індивідуальних особливостей кожного учасника освітнього процесу;

- принцип системності - робота комітету безпеки школи здійснюється в системі освітнього процесу та сукупності взаємодії суб’єктів педагогічного процесу;

- принцип етичності - нерозголошення особистісних проблем учасників освітнього процесу. 
Для досягнення мети в своїй роботі комітет безпеки сприяє продуктивній взаємодії всіх суб'єктів освітнього процесу: учнів, педагогів, батьків, міжвідомчих структур, громадських організацій шляхом проведення діагностичної, консультаційної, просвітницької, профілактичної роботи.

Законодавча база цієї проблеми грунтується на основних нормативно-правових документах, а саме: Конституції України, законі України «Про охорону дитинства», Конвенції ООН про права дитини та інших. Підгрунтям роботи комітету безпеки школи є Конвенція ООН про права дитини, яка чітко визначає обов'язки держави щодо реалізації права дитини на навчання в безпечних умовах.

В школі особлива увага приділяється забезпеченню безпеки всіх учасників освітнього процесу. Комітет безпеки першочерговим завданням вбачає посилення заходів щодо профілактики негативних явищ в шкільному середовищі. В центрі уваги комітету безпеки освітнього закладу виступають різного роду ситуації, конфлікти, які спричиняють фізичну, психологічну небезпеку, почуття незахищеності.

3 урахуванням вищезазначеного, за ініціативи створеного комітету безпеки створюється модель реалізації просвітницьких, профілактичних заходів з метою створення безпечного шкільного середовища.

Система профілактичної роботи комітету містить наступні компоненти:

- просвіта всіх учасників освітнього процесу, громадськості;

- створення позитивного психологічного клімату в освітньому закладі й родинах;

- робота членів комітету 3 батьками, педагогами, учнями, спрямована на зняття факторів, що спонукають чи провокують небезпечні ситуації;

- систематичний контроль і врахування динаміки змін в різних конфліктних, небезпечних ситуаціях;

- при потребі - переадресування до відповідних органів та установ.

Виявлення небезпечних ситуацій в учнівському середовищі передбачає:

- бесіди 3 педагогічними працівниками, персоналом школи, батьками;

- спостереження за здобувачами освіти під час перерв;

- діагностика, аналіз анкет школярів;

- бесіди і консультації з учнями, діти які стикаються з проблемами або самі провокують їх.

Вся робота здійснюється поетапно. 
Очікуваний результат:

- зниження чинників ризику та небезпеки;

- створення комфортного шкільного середовища;

- виявлення ресурсів учасників освітнього процесу для подолання ними небезпечних ситуацій.

Спланована та проведена таким чином робота надає можливість прорахувати можливі ризики та небезпеки в освітньому середовищі, спланувати шляхи їх уникнення, оптимізувати міжособисті стосунки, здійснювати психологічний, фізичний захист школярів.

\section{Література:}

1. Маслоу А. М31 Мотивация и личность. 3-е изд. / Пер. с англ. СПб.: Питер, 2019. - 400 с.

2. Обеспечение психологической безопасности в образовательном учреждении: практическое руководство/Под ред. И.А. Баевой. СПб.: Речь, 2006. - 288 с. 